\title{
Identification of Sand Mineral Content at Beach Tourist Attractions in Sampang Regency through X-Ray Fluorescence and X-Ray Diffraction Testing
}

\author{
Idon Joni ${ }^{1}$ and Sandi Vikki Ariyanto ${ }^{1}$ \\ ${ }^{1}$ Department of Informatics, Faculty of Engineering, Universitas Madura, Madura, Indonesia
}

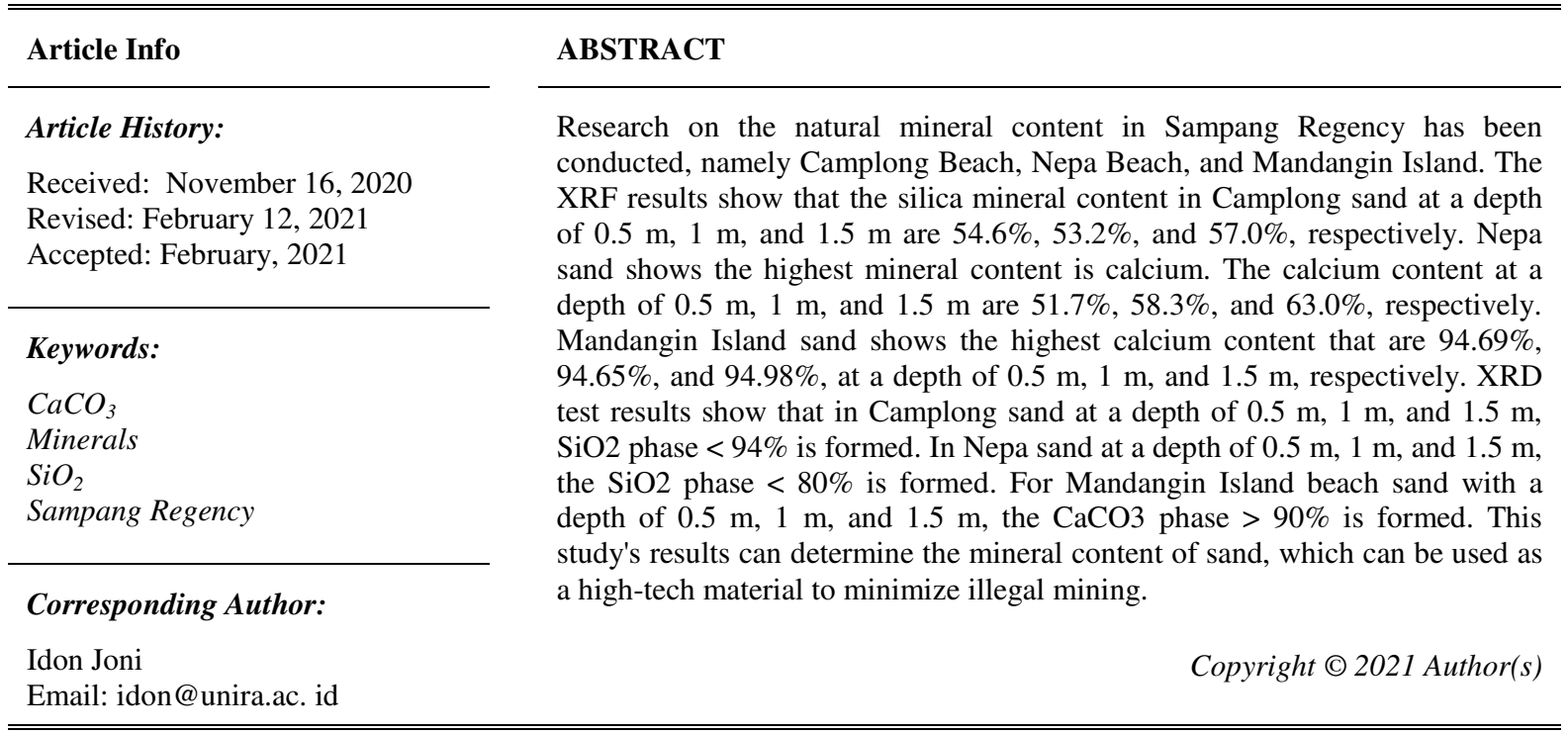

\section{INTRODUCTION}

Indonesia is a country that has abundant natural resources such as oil, gas, and other minerals. One of them is natural minerals found in Sampang Regency, namely Camplong Beach, Nepa Beach, and Mandangin Island, mostly white sand beaches. These three places have much illegal mining along the coast. Some of the illegal miners' products are sold in raw form or used by themselves, while some others are used as building materials that have low economic value. Further processing of sand may yield high economic value, which may have the potential for many applications.

Visually, the sand along the coastline of these three places (Camplong Beach, Nepa Beach, and Mandangin Island Beach) has almost the same characteristics, brownish-white sand. Theoretically, based on these observable facts, the three sites are likely to contain silicon $(\mathrm{Si})$ and calcium $(\mathrm{Ca})$, in the form of $\mathrm{SiO}_{2}$ and $\mathrm{CaCO}_{3}$ phases, which have the potential to become natural minerals for high technology utilization (e.g., $\mathrm{SiO}_{2}, \mathrm{CaCO}_{3}$ ) (Munasir et al., 2012). However, to support this utilization, further synthesis methods such as coprecipitation, precipitation, sol-gel, etc. are needed to form nanomaterials from the sand.

Geographically, Sampang Regency is located between $113^{\circ} 08^{\prime}-113^{\circ} 39^{\prime}$ East Longitude and $06^{\circ} 05^{\prime}-07^{\circ} 13^{\prime}$ South Latitude which covers a land area of $1,233.30 \mathrm{~km}^{2}$. Camplong beach tourism spots are located in Tambaan village, Nepa beach tourism is located in Nepa Village, while the island Mandangin is one of the tourist attractions that can be reached by motorized boat from Tanglok port. The map of Sampang Regency is provided in Figure 1. 


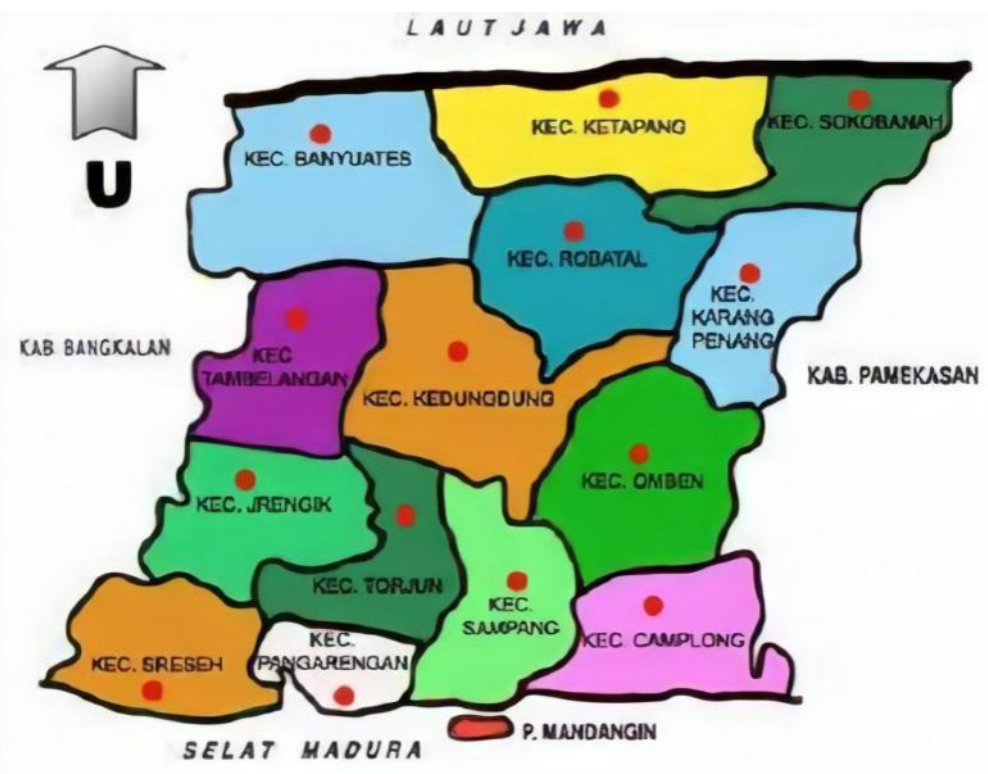

Figure 1. Map of Sampang Regency

Sand is a coarse material that generally measures between 0.0625 and 2 millimeters. The sandforming material is silica $\left(\mathrm{SiO}_{2}\right)$, but several tropical and sub-tropical beaches are generally formed by calcium carbonate $\left(\mathrm{CaCO}_{3}\right)$ sand. The color of the sand depends on the basic material that forms it (Muliawan, 2017). Calcite sand is formed from the deposition of marine animal shells. In contrast, silica sand results from weathering of rocks containing major minerals such as silica, which are then carried by water or wind that settles on the beach. Silica sand made of $\mathrm{SiO}_{2}, \mathrm{Al}_{2} \mathrm{O}_{3}, \mathrm{CaO}, \mathrm{Fe}_{2} \mathrm{O}_{3}, \mathrm{MgO}$, and $\mathrm{K}_{2} \mathrm{O}$ has a clear color depending on the impurity (Setiawan, 2018). The purity of beach sand varies depending on the process of formation.

Beach sand is mostly found in coastal areas and some shallow oceans. Sand can be classified physically based on the shape, size, color, and density of the sand (Saniah et al., 2014) or based on the minerals it contains. Sand mineral content can be determined using X-ray Fluorescence (XRF) and Xray Diffraction $(\mathrm{XRD})$.

The formation of white-sand beaches is related to the abundance of organisms that form sand deposits. The abundance of sand in the Sampang Regency makes it easy for illegal miners to collect and sell, resulting in low selling prices and also impacting the ecosystem in that place. This research is critical because it is being conducted for the first time and improves the local community's economy. Figure 2 shows beach sand at Camplong Beach, Nepa Beach, and Mandangin Island. In this case, it is necessary to test the sand content to determine with certainty the mineral content of sand on Camplong Beach, Nepa Beach, and Mandangin Island using XRF and XRD measurements.

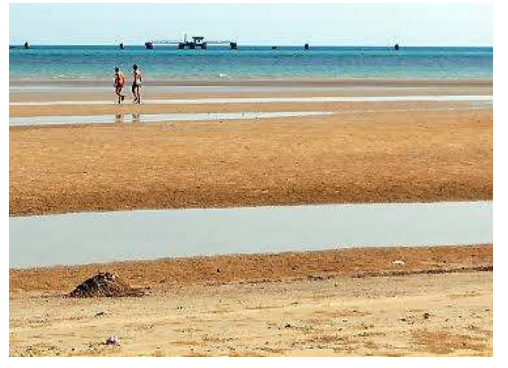

(a)

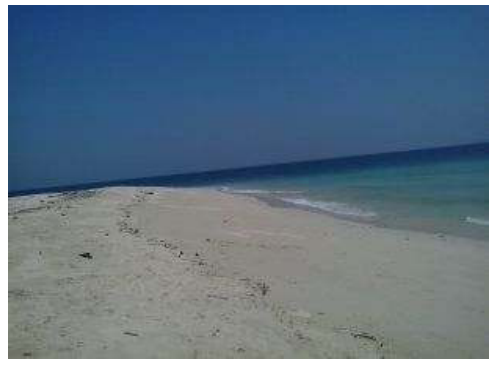

(b)

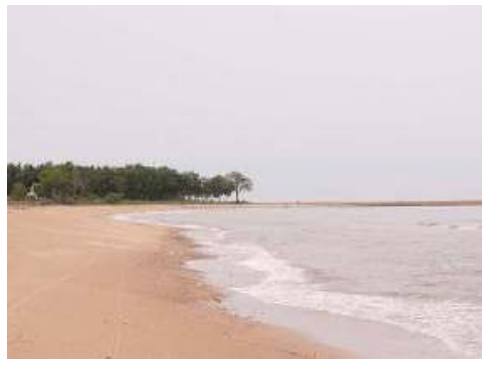

(c)

Figure 2. (a) Sand Beach Camplong Tourism; (b) Mandangin Island Tourism Sand; (c) Sand Beach Tourism Nepa 

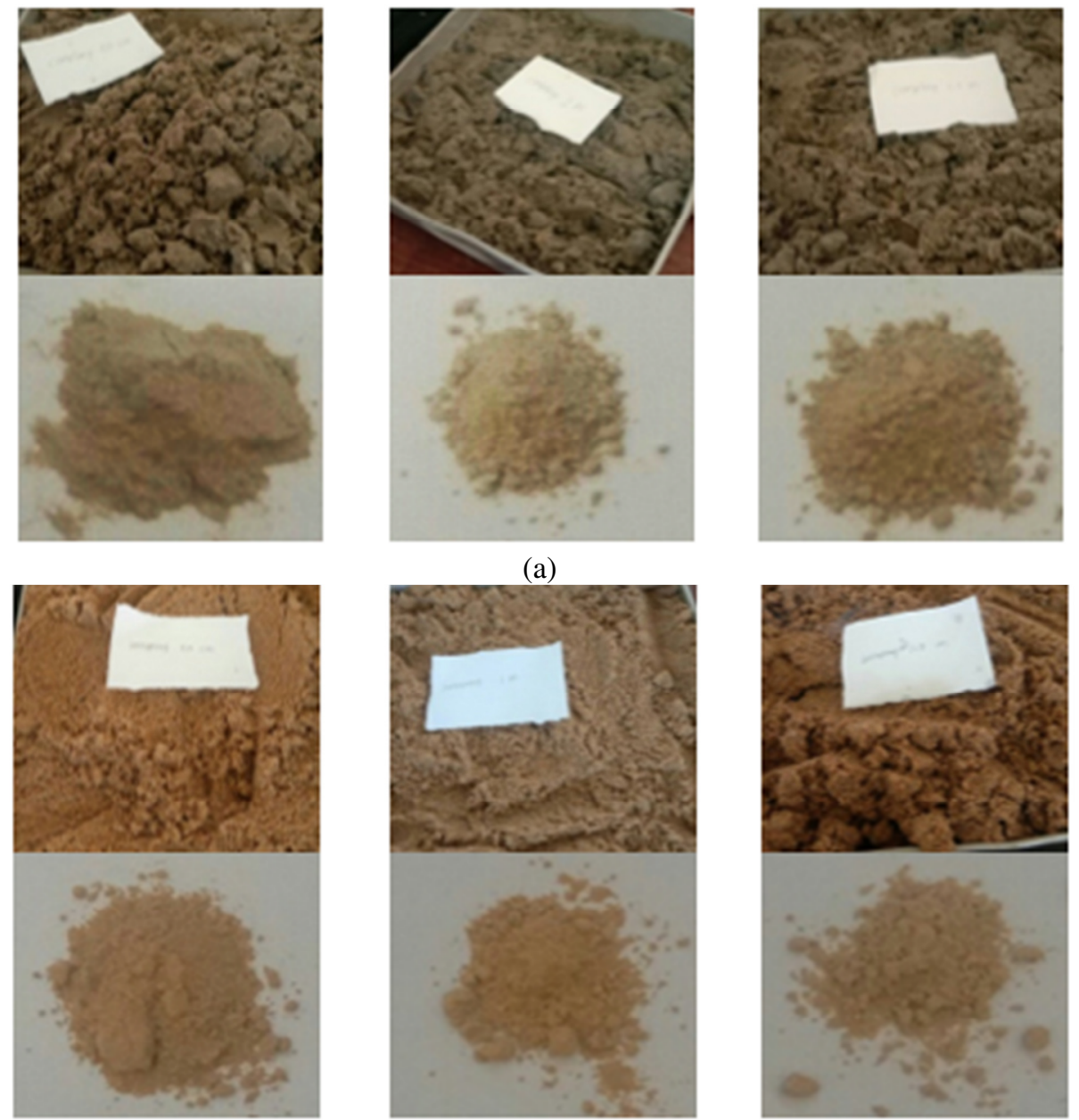

(b)
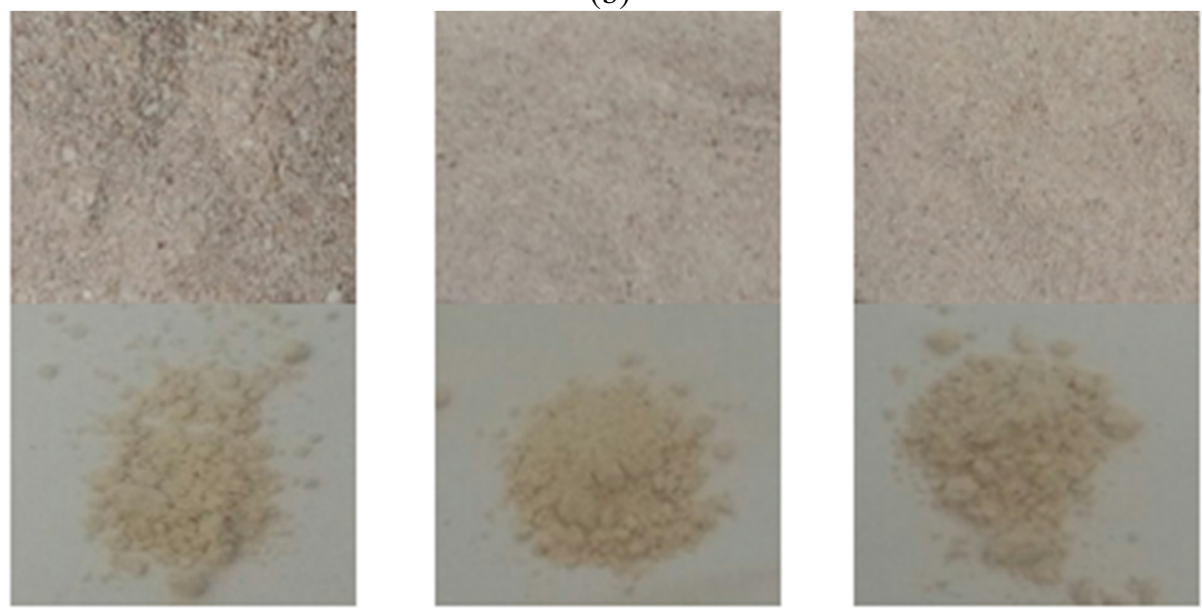

(c)

Figure 3. Characteristic and color of Sand Beach Tours (a) Camplong (b) Nepa (c) Mandangin Island before and after process

\section{METHOD}

Sand samples were collected from three different places: Camplong Beach, Nepa Beach, and Mandangin Island Beach at different depths $(0.5 \mathrm{~m}, 1 \mathrm{~m}$, and $1.5 \mathrm{~m})$. This variation aims to determine 
Joni and Ariyanto: Identification of Sand Mineral Content at Beach Tourist Attractions in Sampang Regency

the level of purity and mineral content of sand near the surface and underneath of the land. The sampling process uses a hoe to perforate and take sand while measuring the variation in depth using a rolling meter. The initial stage of sample preparation is sand moisture removal by heating using an oven at $100{ }^{\circ} \mathrm{C}$ for 24 hours. The dried samples were sieved using a flour sieve to separate small rocks and sand. After that, the grinding process using a mortar was done until the sand completely smooth. The last stage was separation with a sieve size of 300 meshes to obtain fine sand. The sand results obtained were tested using XRF and XRD.

\section{RESULTS AND DISCUSSION}

Initial observations of the beach sand from the three places indicate that the sand is relatively coarse with different colors, namely blackish yellow, brownish-white, and white. The color of the sand determined by its mineral content. Visual observation reveals that sand sourced from 3 different places changes colors after treatment, as in Figure 3.

Based on the XRF results in Table 1, calcium content is dominating (>90\%) in Mandangin Island, followed by strontium, while the rest is quite small amount impurities $(<1 \%)$. There is not much difference in calcium concentration at different depths. The highest calcium content is $94.98 \%$ at a depth of $1.5 \mathrm{~m}$. It is possible that at a depth of $1 \mathrm{~m}$ there may be higher impurity deposits causing calcium purity to decrease or some calcium bound to the impurity. $\mathrm{Sr}$ (strontium) presence in the sand is related to the abundance of sediment-forming organisms (Zuraida et al., 2018). Relatively low concentration $(<5 \%)$ of other minerals in Mandangin beach sand suggest high calcium purity in comparison with two other beaches (Noviyanti et al., 2013). Calcium or $\mathrm{CaCO}_{3}$ (calcite) is carbonic sediment, widely used for Portland cement, steel refining, paper industry, building materials, paint, and many others (Munasir et al., 2012). High calcium content causes the dominant white-color sand.

The beach sand on Camplong Beach at depths of $0.5 \mathrm{~m}, 1 \mathrm{~m}$, and $1.5 \mathrm{~m}$ is mostly silicon, followed by calcium and iron. In general, the XRF results showed that the silicon at Camplong increased according to the depth level, except at $1 \mathrm{~m}$ depth. This decrease is probably due to the large number of impurities deposited at a depth of $1 \mathrm{~m}$. The highest percentage of silicon was found at a depth of $1.5 \mathrm{~m}$. Silicon is potential for ceramics, glass, plates. When mixed with limestone and water, silicon forms cement (Munasir et al., 2012).

In general, the dependence of the dominant mineral content on the sample depth was not found. From the variation in-depth in the three places studied, there was only a change in mineral quantity, without discovering new minerals from different depths. On the deeper coast of Nepa, only calcite concentrations have increased. This can occur due to dirt on the sand that has been swept away or carried away by rain/waves, or the deposition of calcite minerals originating from marine animal shell sediments (Rahmaniar et al., 2015).

XRD results showed the crystallinity of the sample, as shown in Figure 4. The diffraction peaks were quite high with a narrow peak area. Further analysis was carried out using Match software for peak-matching with the database. This analysis allows the identification of phase, crystal structure, cell parameters, density, and Miller index.

Table.1 XRF test results from the sand of the Camplong Beach, Nepa Beach, and Mandangin Island

\begin{tabular}{lcccc}
\hline \multirow{2}{*}{ Research Place } & \multicolumn{4}{c}{ Elements } \\
\cline { 2 - 5 } & $\begin{array}{cccc}\text { Ca (calcite) } \\
\text { \% }\end{array}$ & $\begin{array}{c}\text { Si (Silicon) } \\
\text { \% }\end{array}$ & $\begin{array}{c}\text { Fe (Ferit) } \\
\text { \% }\end{array}$ & $\begin{array}{c}\text { Sr (Stronsium) } \\
\text { \% }\end{array}$ \\
\hline Camplong Beach $(0.5 \mathrm{~m})$ & 37.60 & 54.60 & 3.65 & 0.00 \\
Camplong Beach $(1 \mathrm{~m})$ & 40.60 & 53.20 & 2.51 & 0.00 \\
Camplong Beach $(1.5 \mathrm{~m})$ & 37.20 & 57.00 & 2.78 & 0.00 \\
Nepa Beach $(0.5 \mathrm{~m})$ & 51.70 & 22.80 & 19.00 & 0.00 \\
Nepa Beach $(1 \mathrm{~m})$ & 58.30 & 24.30 & 12.40 & 0.00 \\
Nepa Beach $(1.5 \mathrm{~m})$ & 63.00 & 21.10 & 10.40 & 0.00 \\
Mandangin Island (0.5 m) & 94.69 & 0.00 & 0.00 & 3.62 \\
Mandangin Island (1 m) & 94.65 & 0.00 & 0.00 & 3.78 \\
Mandangin Island (1.5 m) & 94.98 & 0.00 & 0.00 & 3.88 \\
\hline
\end{tabular}




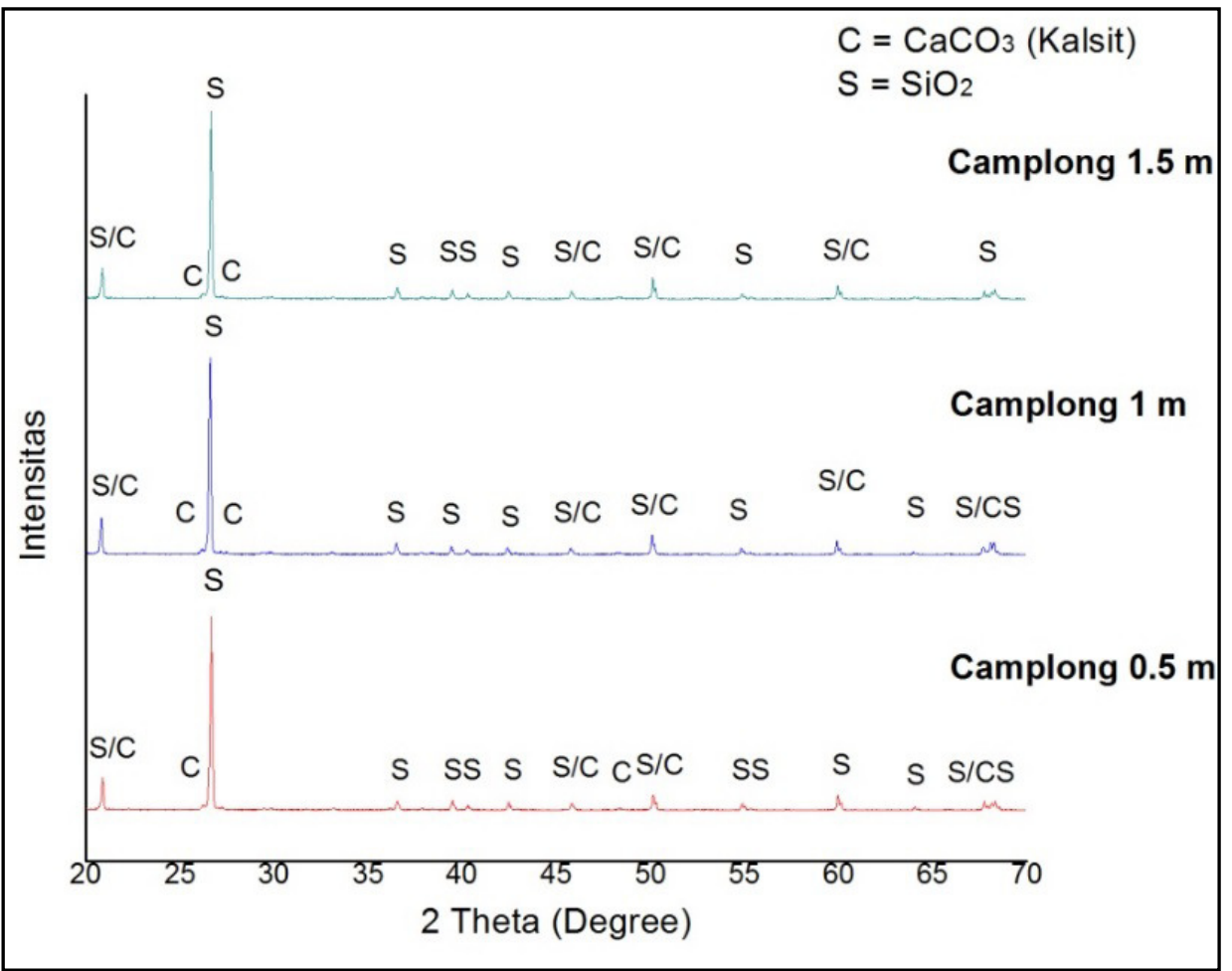

Figure 4. X-ray Diffraction Results of Camplong Beach Sand

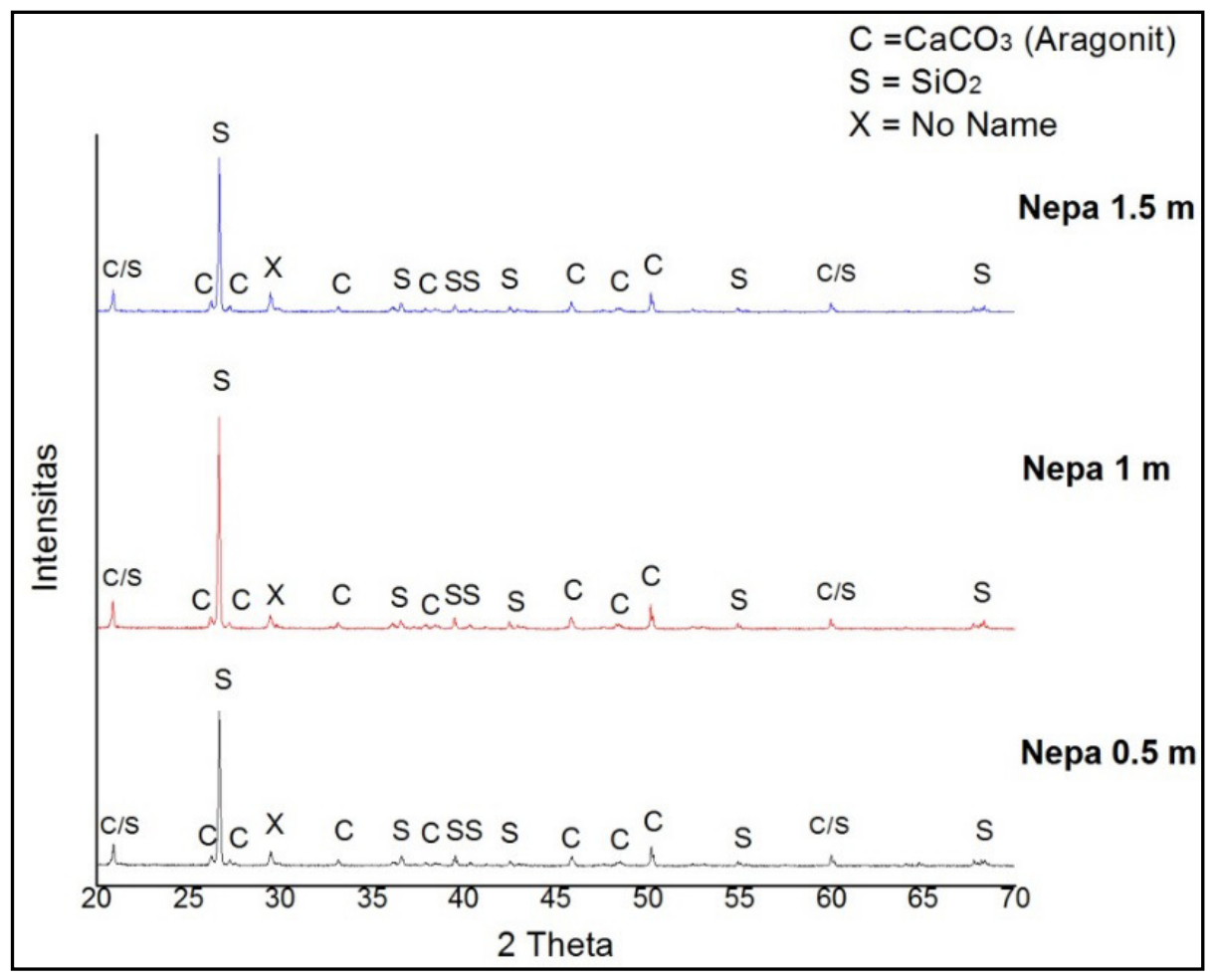

Figure 5. X-ray diffraction results of sands form Nepa Beach

The XRD pattern of sand with a depth of $0.5 \mathrm{~m}, 1 \mathrm{~m}$, and $1.5 \mathrm{~m}$ at Camplong Beach shows the presence of $\mathrm{SiO}_{2}(<93 \%)$ and $\mathrm{CaCO}_{3}(<7 \%)$ phases (Figure 4). The deeper the sampling is, the lower 
Joni and Ariyanto: Identification of Sand Mineral Content at Beach Tourist Attractions in Sampang Regency

the percentage of $\mathrm{SiO}_{2}$. This may be due to the bonding of the silicon with other minerals or the deposition of impurities increasing with depth. This may occur because silica sand has a combined composition of $\mathrm{SiO}_{2}, \mathrm{Al}_{2} \mathrm{O}_{3}, \mathrm{CaO}, \mathrm{Fe}_{2} \mathrm{O}_{3}, \mathrm{MgO}$, and $\mathrm{K}_{2} \mathrm{O}$ which is often transparent without impurities (Heri et al., 2012). At shallow depths, impurities are carried away by the waves so that impurity levels are reduced and the purity of silica increases (Sumarno et al., 2015).

Sands in Nepa Beach at a depth of $0.5 \mathrm{~m}, 1 \mathrm{~m}$, and $1.5 \mathrm{~m}$ contain mostly calcium, followed by silicon and iron. Calcium content in Nepa Beach increases with depth. The highest calcite content is $63 \%$ at a depth of $1.5 \mathrm{~m}$. Relatively high iron content (10-20\%) causes the beach to seems slightly dark/brown (Alimin et al., 2016).

In Nepa sand with a depth of $0.5 \mathrm{~m}, 1 \mathrm{~m}$, and $1.5 \mathrm{~m}, \mathrm{SiO}_{2}(<80 \%)$ and $\mathrm{CaCO}_{3}(<20 \%)$ phases are formed (Figure 5), with the presence of several medium and small peaks at an angleof $29.42^{\circ}$ theta which indicates that $\mathrm{Fe}$ is bound to other compounds. This result is inversely proportional to the XRF results that are predominantly calcite. This difference may arise because in XRD the phase formed is $\mathrm{CaCO}_{3}$ (Aragonite). Aragonite is a carbonate mineral that is formed through biological and physical processes, including precipitation from the marine environment with a metastable phase that is easily decomposed and binds to other compounds. Energy is required to turn into a stable calcite phase (Wahyuni et al., 2015). The presence of high iron peaks in the XRF results indicates that the unidentified peaks above can be attributed to iron bound to other compounds or impurities to form Pigeonite (Matteo et al., 2011).

Sand at a depth of $0.5 \mathrm{~m}, 1 \mathrm{~m}$, and $1.5 \mathrm{~m}$ on Mandangin Island contains a $\mathrm{CaCO}_{3}$ phase $(>95 \%)$ and a strontium phase $(<5 \%)$, as shown in Figure 6. Strontium binds to other impurities to form a second phase, namely strontium pumbate (Chizhova \& Klyndyuk, 2013). The high concentration of $\mathrm{CaCO} 3$ in this area can be seen from the white sand along the coastline. This is possible because this place is an island where many small shelled animals have become sand which contains shellfish powder $98.7 \%$ CaCO3 (Rahmaniar et al., 2015).

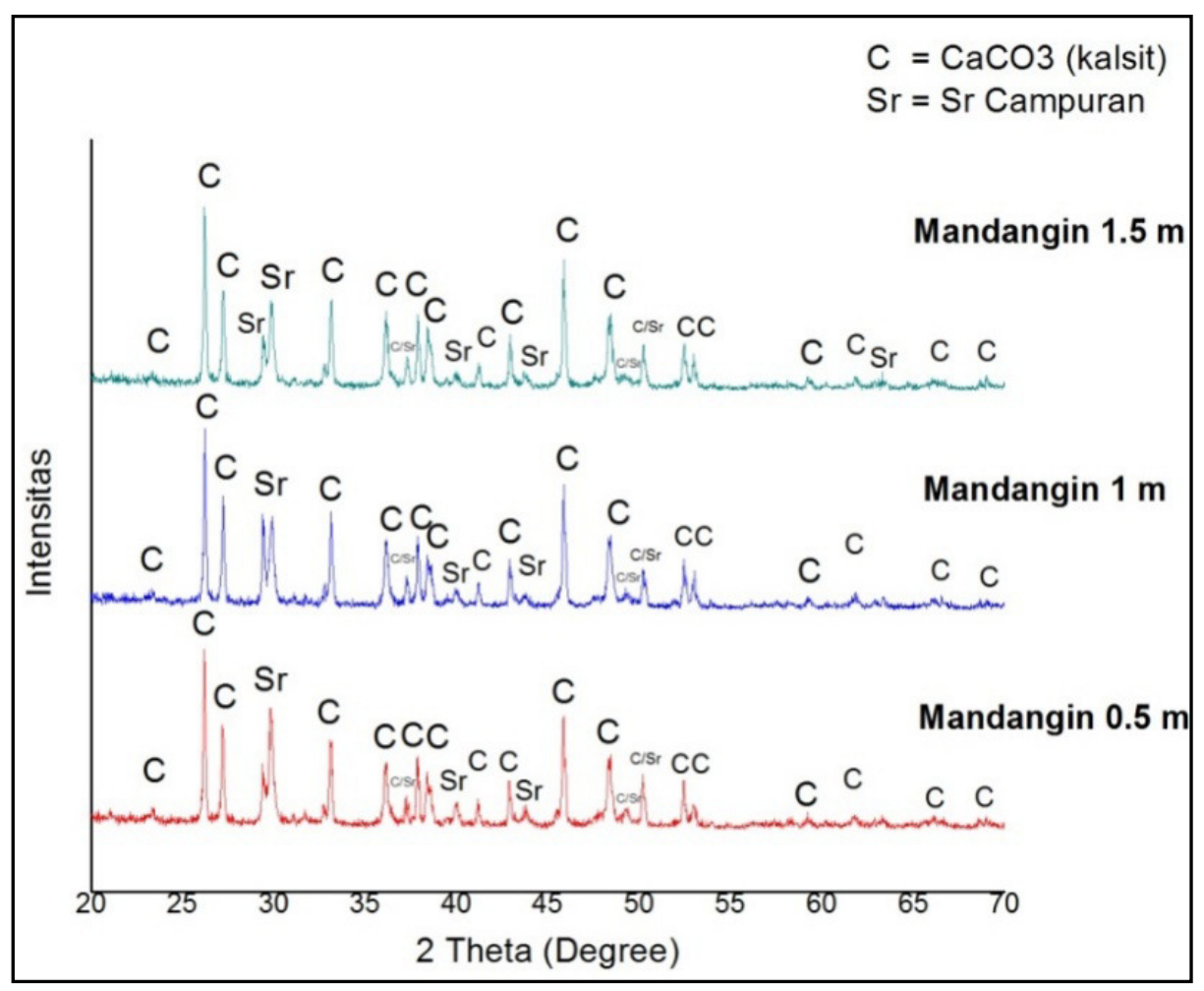

Figure 6. X-ray Diffraction Results of Mandangin Island Beach Sand 


\section{CONCLUSION}

The XRF analysis shows that the highest mineral content of silicon in the Camplong sand for a depth of $0.5 \mathrm{~m}, 1 \mathrm{~m}$, and $1.5 \mathrm{~m}$, namely $54.6 \%, 53,2 \%$, and $57.0 \%$, respectively. Nepa sand shows the highest mineral content is calcium. The calcium content at a depth of $0.5 \mathrm{~m}, 1 \mathrm{~mm}$, and $1.5 \mathrm{~mm}$ are $51.7 \%, 58.3 \%$, and $63.0 \%$, respectively. Sand in Mandangin Island shows the highest mineral content of calcium. The calcium content for a depth of $0.5 \mathrm{~m}, 1 \mathrm{~m}$, and 1.5 is $94.69 \%, 94.65 \%$, and $94.98 \%$. $\mathrm{XRD}$ results show that the mineral content with varying depths in the Camplong sand is formed in $\mathrm{SiO}_{2}(<93 \%)$ and $\mathrm{CaCO}_{3}\left(\right.$ Calcite) phases are $(<7 \%)$. On Nepa Beach sand, $\mathrm{SiO}_{2}(<80 \%)$ and $\mathrm{CaCO}_{3}$ (Aragonite) $(<20 \%)$ are formed. On the sand beaches of Mandangin Island, $\mathrm{CaCO}_{3}(>95 \%)$ and $(<$ $5 \%)$ Sr. Mandangin Island sand shows the highest calcium content that are $94.69 \%, 94.65 \%$, and $94.98 \%$ at a depth of $0.5 \mathrm{~m}, 1 \mathrm{~m}$, and $1.5 \mathrm{~m}$, respectively.

\section{ACKNOWLEDGEMENT}

This research is supported and funded by The Ministry of Research, Technology, and Higher Education of The Republic of Indonesia. The author also would like to thank the editorial team of the Jurnal Ilmu Fisika (JIF) and two anonymous reviewers.

\section{REFERENCE}

Alimin., Maryono., Putri, S.E. (2016). Analisis Kandungan Mineral Pasir Pantai Losari Kota Makassar Menggunakan XRF dan XRD. Jurnal Fakultas Maematika. dan Ilmu Pengetahuan Alam Universitas. Negeri Makassar, 17, 2, 19-23.

Chizhova, E.A. and Klyndyuk, A. (2013). Synthesis and thermoelectric properties of ceramics based on bariumstrontium meta plumbates. Glas. Phys. Chem., 39, 4, 453-457, DOI: 10.1134/S1087659613040068.

Heri, J., Yunigtyastuti., Syakur, A. (2012). Studi Arus Bocor Permukaan Bahan Isolasi Resin Epoksi Silane Dengan Variasi Pengisi Pasir Silika (Dengan Polutan Pantai). TRANSMISI, 14, 1, 20-37, doi: 10.12777/transmisi.14.1.20-37.

Matteo, A., Camara, F., Domeneghetti, M.C., et al.., (2011). HT P21/c = C2/c phase Transition and inetic of Fe $\mathrm{F}^{2+}$ - Mg Order disorder of an Fe-poor pigeonite : Implications for the cooling history of ureilites. contrib mineral petrol. 162, 599-613. DOI : 10.1007/s00410-011-0614-7

Muliawan, A. (2017). Identifikasi Material Pasir Desa Sambera Marangkayu Menggunakan XRF Dan XRD. in Seminar Nasional dan Workshop Geofisika FMIPA Universitas Mulawarman 08 - 10 Desember 2017, Samarinda, 1-5.

Munasir., Triwikantoro., Zainuri, M., et al. (2012).Uji XRD Dan XRF Pada Bahan Meneral (Batuan Dan Pasir) Sebagai Sumber Material Cerdas $\left(\mathrm{CaCO}_{3}\right.$ Dan $\left.\mathrm{SiO}_{2}\right)$. Jurnal Penelitian Fisika dan Apikasinya., 2, 1, 20-29.

Noviyanti., Jasruddin., Sujiono, E.H. (2013). Karakterisasi Kalsium Karbonat $\left(\mathrm{Ca}\left(\mathrm{CO}_{3}\right)\right)$ Dari Batu Kapur Kelurahan Tellu Limpoe Kecamatan Suppa. Jurnal Sains dan Pendidikan Fisika., 11, 2, 169-172.

Rahmaniar., Rejo, A., Priyanto,G., et al. (2015). Karakterisasi Kompon Karet Dengan Menggunakan Ekstrak Kayu Secang, Pasir Kuarsa Dan Kulit Kerang. Jurnal Teknologi Inustri. Pertanian., 25, 3, 2-3.

Saniah., Purnawan, S., Karina, S. (2014). Karakterisasi dan kandungan mineral pasir pantai lhok mee, beureunut dan leungah. Kabupaten aceh besar. Jurnal ilmu perairan, pesisir dan perikanan. Universitas Syiah Kuala. Banda Aceh.

Setiawan, A.A (2018). Pengaruh Pasir Kuarsa Sebagai Material Pengganti Semen Pada Campuran Beton Self Compacting Concrete (Scc) Terhadap Kuat Tekan Dan Porositas Beton. Jurnal Rekayasa Teknik Sipil, $1,1,160-166$.

Silvia, L., Zainuri, M., Suasmoro., et al.., (2018). Analisis Kandungan Mineral Pasir Pantai Di Kabupaten Pacitan Dengan Metode Ekstraksi. Seminar Nasional Edusainstek, 16-20.

Sumarno., Novarita, P.N.T., Januarty, M., et al.. (2015). Pemurnian Pasir Silika dengan Metode Leaching Asam dan bantuan Sonikasi. Proceeding Seminar Nasional Kejuangan, 12, 1-8.

Wahyuni, S., Darvina, Y., Ramli. (2015). Optimalisasi Temperatur Kalsinasi Untuk Mendapatkan Kalsit- Caco3 Dalam Cangkang Pensi (Corbicula Moltkiana) Yang Terdapat Di Danau Maninjau. Pillar Phys., 6, 8188. 
Joni and Ariyanto: Identification of Sand Mineral Content at Beach Tourist Attractions in Sampang Regency

Zuraida, R., Gerhaneu, N.Y., Sulistyawan, I.H. (2018). Karakteristik Sedimen Pantai Dan Dasar Laut Di Teluk Papela, Kabupaten Rote, Provinsi Ntt. Jurnal Geologi Kelautan, 15, 2, 81-94. 